\title{
Synopsis The Anaga Park: An Access to the Root of Tenerife Island, Canary Archipelago, Spain
}

A preservation program of fossil and active volcanic fields is currently working in the Canary archipelago, Spain. The program is based on a domestic classification of the natural areas of the islands, which broadly matches the typology and classification criteria of the World Conservation Union.

The Canary Archipelago (CA) consists of 7 islands and a few small barren islands. Their total area is about $7500 \mathrm{~km}^{2}$ and they are located $1100 \mathrm{~km}$ from the Spanish mainland, and some $100 \mathrm{~km}$ from the African coast. From a historical, economical, political and sociocultural point of view, the CA is completely European.

Biogeographically, the CA forms part of the Macronesia region (in Greek "Happy Islands"). This region is formed by the Atlantic islands of the Azores, Madeira, Canaries and Cape Verde, as well as the group of islets called Salvajes (Wild). Geologically, the CA is an excellent example of structural control on the growth of large oceanic-island volcanoes. Volcanism in the Canary Islands is associated with the transition from continental (Africa) to oceanic (Atlantic) lithosphere within the African plate, the effects of the tectonics of the nearby Atlas Mountains, and the very slow movement (about $1 \mathrm{~cm} \mathrm{yr}^{-1}$ for the last 60 million years) of the African plate.

Tenerife is the largest $\left(2058 \mathrm{~km}^{2}\right)$ and highest island of the $\mathrm{CA}$, and one of the most complex from a volcanological point of view. In the past, many singular geobiological characteristics of the island have been overshadowed by the impressive Teide volcano: the third largest volcano on earth, together with Mauna Loa and Mauna Kea and, officially, the highest mountain in Spain (3715 m). However, new studies, which tackled the ecosystems of Tenerife from a multidisciplinary point of view (not exclusively restricted to volcanic processes) have evidenced the natural features and scientific data of other areas. The recent characterization of the Anaga Park, NE Tenerife, addresses one such case, not only because it displays one of the most spectacular and beautiful cliffs and landscapes of the whole archipelago, but also due to its peculiar diversity of ecosystems.

The Anaga Park covers 14418 ha and hosts 3 municipal domains: Santa Cruz (about $77 \%$ of the protected area), La Laguna (16\%) and Tegueste (7\%), broadly representing around $8 \%$ of the surface of the whole island. Anaga is a real geobiological paradise, where altered ba- saltic lava flows, intercalated with pyroclastic layers, can be observed in several outcrops. In addition, numerous dykes cut these rocks and, in some places, light trachytic and phonolitic plugs crown the crests of the Anaga heights. Some uplifted beaches with fragmented shells can be seen along the coast of Anaga massif; e.g. Tachero Beach at the north of the Taganana area.

Intense erosion is shown by the wide heads of the valleys and the thick piedmont deposits above the shoreline. The landscape is offset by forest zones, which prevent erosion and greatly contribute to the infiltration of water into the subsoil. In fact, only the high quantity of water would be sufficient reason to protect and extend this area. The most representative forest of Anaga is the "Laurisilva", today concentrated on the peaks of Anaga, as well as on other areas of the Tenerife island such as Teno, and La Esperanza Dorsal Ridge.

This unusual coalescence of geomorphology, volcanic structures and forestry, make up an incomparable natural scenario; nevertheless, there are other additional scientific features which make the Anaga Park unique: it shows the intrusive and mineralized outcrops which were formed during the first stages of submarine volcanism and other associated processes that built the basement of the Tenerife Island.

Many researchers intended to establish an exact age for the rocks of the area throughout the K-Ar method. The first KAr data were estimated as mid-Miocene (15.7 Ma) (1). This determination differs from more recent $\mathrm{K}$-Ar data by at least 10 Ma considering data from other authors (2-4). The main problem for obtaining an adequate age determination is that the most relevant rocks are quite altered and therefore not useful for dating. The extremely dense dyke intrusion makes remnant magnetism and paleomagnetic methods invalid. As a consequence, an important gap of age determinations exists.

Nevertheless, if the first K-Ar dating (1) is taken into account, the minimum age of the Taganana area is mid-Miocene, which is in accordance with an age of more than 15.7 Ma for the Taganana rocks (2). Thus, the Taganana area, considered as mid-Upper Miocene (older than $10 \mathrm{Ma}$ ) (5), constitutes a real Volcanic Rift Zone identified by a dense NE-SW striking dyke swarm, tectonically overturned to the northwest. The outcrop of the oldest rocks of the Tenerife island in the Anaga Park allows easy sampling in situ of both the plutonic intrusions (syenites and gabbroids) and the spectacular sheet of dyke intrusion (6).

Besides this unique characteristic of Anaga, based on its accessibility to the root of the Tenerife Island, this park displays a further characteristic which emphasizes the interest of its preservation: the occurrence of oxide and sulfide minerals (magnetite, ilmenite and pyrite) and hydrothermal jasper-bearing infills. The former mineralization occurs as large, oreenriched patches and fracture fillings in the syenites and alkali gabbroids. The jasper occurs along with celadonite in association with minor hematite, magnetite, carbonate (mainly siderite), kaersutite, calcite, and traces of ilmenite associated with magnetite. These mineral associations were recently discovered (7) and do not appear in any other part of the island.

Finally, in some places big ferns, locally called "pijarales" can also be found. They are of special interest as they were common in the Mediterranean area during the Tertiary, and now survive as living fossils only in these islands.

\section{References}

\begin{abstract}
Abdel-Monem, A., Watkins, N.D. and Gast, P.W. 1972. Potassium-Argon, volcanic stratigraphy and geomagnetic history of the Canary Islands: Tenerife, La Palma and Hierro. Am. J. Sci. 272, 805-825.

2. Carracedo, J.C. 1975. Estudio Paleomagnetico de la Isla de Tenerife. Thesis, Universitas Complutense de Madrid, Spain. 265 p. (In Spanish).

3eraud, G. 1981. Datations des Reseaux de Dykes et de Roches Volcaniques Sous-Marines par les Méthodes KAr et ${ }^{40} A r-{ }^{39} A r$. Utilisation des Dykes comme Marqueurs de Paleocontraintes. Thesis, University of Nice, France. $146 \mathrm{p}$.

4. Ancochea, E., Fuster, J.M., Ibarrola, E., Cendrero, A., Coello, J., Hernan, F., Cantagrel, J.M. and Jamond, C. 1990. Volcanic evolution of the island of Tenerife, Canary Islands in the light of new K-Ar data. J. Volcan Geothermal. Res. 44, 231-249.

Hernández-Pacheco, A. and Rodríguez-Losada, J.A 1996. Geologìa y estructura del Arco de Taganana. Rev. Soc. Geol. Esp. 9, 169-183. (In Spanish).

6. Rodriguez-Losada, J.A. and Martinez-Frias, J. 1998. Ancient oxide- and sulphide-mineralization in the islands of Tenerife and La Gomera (Canary Archipelago, Spain). Mineral. Depos. 33, 639-643.

. Rodríguez-Losada, J.A., Bustillo, M.A., Martinez-Frías, J. and Delgado, J.A. 1998. Mineral paragenesis and geochemical composition of the hydrothermal mineral geochemical composition of the hydrothermal mineral phases hosted in ankaramite basalts from Punta Poyata (Tenerife island). In: "The Geology and Geophysics of Tenerife Workshop". Marti, J., Dañobeitia, J.J. and Araña, V. (eds). Las Cañadas, Tenerife 10-15 May, 1998. CSIC, MEC and Cabildo Insular de Tenerife, p
\end{abstract}

José Antonio Rodríguez-Losada Departamento de Edafología y Geología

Facultad de Biología

Universidad de La Laguna

38206 La Laguna, Tenerife

Canary Islands, Spain

Jesús Martínez-Frías

Departamento de Geología

Museo Nacional de Ciencias Naturales,

CSIC ${ }^{C}$ José Gutiérrez Abascal, 2

28006 Madrid, Spain

E-mail: martinezfrias@mnen.csic.es 